\title{
Transplantation of mesenchymal stem cells for the treatment of demyelinating diseases
}

\author{
Petriv T. ${ }^{1,2,3}$, Tatarchuk M. ${ }^{1}$, Tsymbaliuk Yu. ${ }^{1}$, Tsymbaliuk V. ${ }^{4}$ \\ ${ }^{1}$ Romodanov State Institute of Neurosurgery of the National Academy of Medical Sciences of Ukraine, Kyiv, Ukraine \\ ${ }^{2}$ Medical Center Hemafund, LTD, Kyiv, Ukraine \\ ${ }^{3} \mathrm{QR}$ Health Solutions, Kyiv, Ukraine \\ ${ }^{4}$ National Academy of Medical Sciences of Ukraine, Kyiv, Ukraine \\ Corresponding author's e-mail: petrivtaras@gmail.com
}

\section{ABSTRACT}

Demyelinating diseases, especially multiple sclerosis is not only medical but also socio-economic issue. Unsatisfactory quality of life and high degree of disability in these patients require the implementation of the advanced treatments, such as stem cell transplantation. Numerous experimental and clinical studies are being conducted, revealing new mechanisms of the action of stem cells in demyelinating diseases. Further research is needed to understand many more aspects of clinical use.

This review is devoted to the use of regenerative cell technologies in the treatment of demyelinating diseases, the current state and prospects of the approach to the treatment of such pathology with stem cells.

KEY WORDS: stem cells; cell transplantation; multiple sclerosis

Multiple sclerosis (MS) is a chronic progressive disease of the central nervous system, mainly with a relapsing-remitting course, which affects people of mostly young working age, and quickly leads to disability [1]. About $3 \%$ of all cases of MS are children, and half of all patients are persons aged $20-40$ years. Only in $20 \%$ of patients, the first signs of the disease appear after 40 years. Women suffer from this disease 2-4 times more often than men [2,3]. Therefore, MS is not only medical but also socio-economic issue.

\section{ETIOLOGY AND PATHOGENESIS OF DEMYELINATING}

\section{DISEASES AND STEM CELLS}

The etiology of MS is insufficiently studied, even at the present stage of medical science. The most common idea is that MS occurs in people who are exposed to negative environmental factors (viral or bacterial infection, insufficient insolation, vitamin $D$ deficiency) on the background of genetic liability $[4,5]$. Thus, among the genes associated with MS, there are alleles HLA-DRB $1{ }^{*} 1501$ and HLA-DRB5 ${ }^{\star} 0101$ of major histocompatibility complex (MHC) class II antigens, alleles of the interleukin 2 (IL-2) and IL-7 receptors [6]. There is also evidence that mutations in the genes of the IL-1 receptor and the IL-1Ra receptor antagonist, the cytotoxic Tlymphocyte-associated antigen 4 (CTLA-4), the genes encoding receptor for the Fc fragment of immunoglobulins and the gene encoding apolipoprotein $\mathrm{E}$ determine the type of clinical course of MS $[7,8]$.

Relapsing-remitting form of MS, which occurs in about $85 \%$ of cases, is characterized by partial regression of neurological deficit between exacerbations. Initially, progressive form of MS is the second most common and is characterized by the absence of periods of remission with a steady increase in neurologic deficit [9].

The pathogenesis of MS is complex, but there is no doubt that it is an immune-mediated disease. One of the key points is the damage of the regulatory function of the immune system, activation of myelin-specific clones $\mathrm{CD}^{+}$and $\mathrm{CD} 8^{+} \mathrm{T}$-lymphocytes with the phenotype of memory cells (differentiation of T-lymphocytes in Tx1 phenotype), as well as functional changes of peripheral blood lymphocytes system. Infiltration of nervous tissue by lymphocytes that pass through the blood-brain barrier can be initiated by the entry of viral or bacterial antigens into the CNS and the expression of their proteins on the membranes of glial cells [10]. Processes such as molecular mimicry and high levels of cytokines, play a role in the occurrence of autoactivation of T-lymphocytes, for which blood-brain barrier is normally impermeable, although these mechanisms are not fully understood [11, 12].

In addition to the inflammatory component, the degenerative process plays an important role in the increase of neurologic deficit in patients with MS. Characteristic of pathologic changes in the CNS, which are a consequence of chronic inflammation are manifested in the form of foci of demyelination, the so-called "plaques". Simultaneously with demyelination, remyelination processes can begin, which are responsible for the remitting course of the disease. However, remyelination processes are insignificant, and the restoration of the myelin sheath is much weaker than its destruction. Disturbances of remyelination processes are associated 
also with decrease in the quantity of oligodendroglial progenitors and their functional immaturity $[13,14]$.

Given the complex pathogenesis of MS, the search for the optimal treatment strategy continues. Steroid hormones and disease-modifying drugs are the treatment of choice in the chronic stage of the disease. Glatiramer acetate and interferon- $\beta$, monoclonal antibodies are diseasemodifying drugs with proven safety. These drugs are used in the treatment of progressive-remitting forms of MS, and their action in the progressive form of the disease did not live up to expectations [15]. The use of stem cells can be an alternative method of treating MS and used in combination with other treatments.

From a practical point of view, mesenchymal stem/stromal cells (MSCs) are of the greatest interest. Friedenstein et al. discovered this type of cells in the bone marrow in 1967. Later they were isolated from adipose tissue, umbilical cord (Warton's gelly), muscles and lungs, placenta. Embryonic stem cells and induced pluripotent stem cells (iPSC) are tumorigenic $[16,17]$. The use of neural stem cells has no special prospects due to the difficulty of obtaining them and increasing the adequate therapeutic dose.

\section{MECHANISIMS OF ACTION OF MESENCHYMAL STEM CELLS IN} DEMYELINATING DISEASES

MSCs were initially considered candidates for transdifferentiation into neurons and glia cells, but over the past few years there has been a paradigm shift in favor of their paracrine properties. It is also known that MSCs modulate innate and adaptive immunity. The key factor influencing their immunomodulatory properties is the local microenvironment [18].

MSC homing is the ability to migrate to the lesion site, depending on both the local microenvironment and the peculiarities of MSC cultivation. Gonzales-Portillo et al. showed that the use of mannitol increases the permeability of hematoencephalic barrier by increasing the gaps between endothelial cells that undergo shortening under its influence. The longer culturing goes, the more passages the cell culture undergoes, the less receptors for chemokines express MSCs and their ability to homing decreases $[19,20]$. Thus, the expression of a membrane protein VLA-4 (very late antigen-4) of the integrins family and matrix metalloproteases (MMP) disappears between passages 3 and 5 in MSCs culture [21]. There is also evidence that MSCs isolated from adipose tissue and umbilical cord express more integrin-a4, a factor that promotes migration, than bone marrow MSCs [22]. Umbilical cord MSCs, compared with adipose tissue and bone marrow-derived MSCs, have the ability to persist in the recipient for up to 3 weeks, as shown by Todeschi et al. [23].

The immunomodulatory properties of MSCs are determined by the ability to suppress $T$ lymphocytes by stopping cell division in the G0-G1 phase of the cell cycle due to a decrease in cyclin $D$ and an increase in p27 [24] and by regulating the Th2/Th1 ratio by activating Treg lymphocytes. In the presence of both autologous and allogeneic MSCs, mature CD25-T lymphocytes differentiate into Treg lymphocytes, which are a he-terogeneous population of cells with the $C D 45^{+} C D 2^{+}$phenotype [25]. The main biological function of Treg is to maintain the balance between lymphocyte populations and immunological tolerance to its own antigens, prevention of the autoimmune process.

In addition to the antiproliferative effect, MSCs affect the maturation of dendritic cells and natural killers (NK), reducing the expression of co-stimulatory and antigen-presenting molecules on antigen-presenting cells [26].

Other immunomodulatory factors are the inhibition of the secretion of proinflammatory cytokines [27]. A key role in this process is played by prostaglandin E2 (PGE2), which is synthesized during the metabolism of arachidonic acid. Some researchers note the effect of PGE2 on the profile of cytokines that are expressed in the cultivation of allogeneic MSCs with activated lymphocytes and dendritic cells. In the presence of proinflammatory cytokines the secretion of PGE2, MSCs increases that in its turn by the principle of negative feedback reduces expression of proinflammatory cytokines [28]. The presence of PGE2 inhibitors neutralizes the immunosuppressive effect of MSCs.
The effect on the humoral immunity is realized through the inhibition of maturation of B-lymphocytes from bone marrow progenitors, suppression of their proliferation and production of immunoglobulins [29].

A number of factors are involved in the implementation of the immunomodulatory effects of MSCs: transforming growth factor- $\beta$ (TGF- $\beta 1$ ), nitric oxide (NO), interleukin-10 (IL-10) [30]. Interestingly, the immunosuppressive properties of MSCs are almost non-existent under normal conditions, but they exist only when they enter the environment in the presence of pro-inflammatory factors such as IL-1, tumor necrosis factor-a (TNF-a), interferon- $\gamma$ [31]. Thus, MSCs pre-cultured with interferon- $\gamma$ more effectively inhibit the graft-versus-host response [32].

The neuroregenerative properties of MSCs are provided by their ability to differentiate into the cells of mesodermal and ectodermal origin (such as neurons and neuroglia cells) both in vitro and in vivo [33]. This is another reason for the possible use of MSCs in the treatment of demyelinating and neurodegenerative diseases. MSCs that underwent predifferentiation in the neural direction after intrathecal transplantation in patients with MS contributed to the improvement of muscle strength and pelvic function [34].

The ability of MSCs to exhibit neuroprotective properties is due to a number of neurotrophic factors, such as nerve growth factor (NGF), brainderived neurotrophic factor (BDNF), and glial-cell derived neurotrophic factor (GDNF).

\section{EXPERIMIENTAL PREREQUISITES FOR CELL THERAPY FOR MS}

The therapeutic properties of MSCs are widely studied in the model of experimental allergic encephalomyelitis (EAE), which is a common model of demyelination in the experiment on animals. The issue of improving the results of treatment of experimental demyelinating CNS injuries by xenotransplantation of umbilical cord MSCs (Warton's jelly) and antiinflammatory IL-10 is studied by S. Toluvani [35]. The study was performed on 3 month-old white outbred female rats with EAE as a model of demyelinating lesion. The course of the disease was estimated using a 6-point scale for assessing the clinical condition of animals, behavioral responses ("open field" test), cell culture, genetic, and morphological studies. It was confirmed that the morphological characteristics of MSCs and their expression of surface markers are maintained during 2 passages of culturing. At a later stages, there are signs of culture degradation and loss of mesenchymal phenotype by cells. PCR revealed that umbilical cord-derived MSCs stransplanted subarachnoid into the cerebrospinal fluid of animals with $E A E$, remain viable for at least 5 days and migrated to different parts of the nervous system. The injection into the cerebrospinal fluid of animals MSCs and anti-inflammatory IL-10 in various combinations contributes to the complete clinical regression of symptoms and recovery of animals up to 32 days of the experiment.

The study of signs of de- and remyelination at the ultrastructural level shows that MSCs inhibit the phenomena of de-myelination in the early stages of the study (35 days), contribute to remyelination of axons. The survival of xenogenic MSCs, their homing and migratory ability to the lesion site in the CNS, have positive effect on the regression of EAE.

Zang et al. in the EAE model showed that intravenous administration of xenogenic human bone marrow MSCs at a dose of $2 \cdot 10^{6}$ into mice immediately after the manifestation of neurologic deficits, contributed to almost complete symptoms regression, by reducing lymphocytic infiltration and demyelination, and in particular due to stimulating oligodendrogenesis by brain-derived neurotrophic factor (BDNF) [36, 37]. The authors emphasize the importance of early administration, which correlates with the severity of the inflammation in the CNS. As a continuation of the concept of MSCs administration in the early stages of the disease, we can consider the work of Kurte et al., who showed that the introduction of allogeneic bone marrow MSCs $\left(2 \cdot 10^{6}\right)$ into the tail vein of mice with EAE significantly improves the condition of animals according to behavioral tests immediately after the onset of neurological deficits [36]. The authors explain the positive effect by a decrease in the level of IL-6. The introduction of MSCs in the late stages of the disease led to the manifestation of 
atypical symptoms, which is associated with an imbalance in populations of Th1 / Th17 lymphocytes, rather than stimulation of Treg lymphocytes [37].

Neuroregenerative mechanisms of MSCs action were shown by Bai et al. [38]. After the administration of allogeneic MSCs of the bone marrow at the dose of $3 \cdot 10^{6}$, they noted an increase in the number of oligodendrocytes and a decrease in the number of astrocytes. Transplanted MSCs were detected in the foci of demyelination. The opposite data were obtained by Nessler et al. [39], who did not show an effect in the form of remyelination and any reaction of glial cells after the administration of the same dose of allogeneic MSCs into rats.

\section{CLINICAL STUDIES OF THE APPLICATION OF MESENCHYMAL STEM CELLS IN DEMYELINATING DISEASES}

Encouraging results from preclinical studies have initiated a number of clinical studies. Lu et al. used allogeneic MSCs of the umbilical cord for the treatment of 8 patients with secondary progressive MS by combined intravenous and intrathecal administration of $20 \cdot 10^{6}$ cells, 1 time in 7 days for 21 days. In patients, there was a decrease in the frequency of periods of exacerbation of MS by more than $60 \%$ after the treatment [40].

Interesting data were obtained in a study [41], where peripheral blood obtained from a patient with MS was cultured in vitro together with MSCs of the umbilical cord (in a ratio of 1:5, respectively). The obtained results showed an improvement in the functional state of regulatory T-lymphocytes, an increase in the concentration of transforming growth factor- $\beta 1$, prostaglandin E2 and anti-inflammatory cytokines.

Mohyeddin Bonab et al. used intrathecal injection of autologous bone marrow MSCs for the treatment of patients with primary-progressive and secondary-progressive forms of MS. Control neurological examination was performed every month for 13-26 months, MRI control was performed in a year after treatment. Intrathecal administration of MSCs contributed to the regression of neurological deficit. Side effects of intrathecal injections were mild transient headache in 9 patients and aseptic meningitis in 2 patients (verified by cerebrospinal fluid culture) [42].

The combination of intravenous and intrathecal routes of MSCs administration to improve treatment efficacy contributed to the regression of neurological deficits and improved the immunoregulatory index (increased populations of CD4, CD25 and Treg lymphocytes) in the study of Karussis et al. [43].

The authors of another study [44] found that intrathecal injection without intravenous administration does not cause a systemic response in patients with MS. In 23 patients with MS who underwent only intrathecal injections, no significant changes in the expression of FOXP3, IFN- $\gamma$, TGF- $\beta$, IL- 4 , IL-10, IL- 6 by peripheral blood mononuclear cells were recorded. Usually after repeated injections of MSCs, patients feel well, although the authors reported a case of transient encephalopa- thy and seizures in one patient after the injection of MSCs at a dose of $100 \cdot 10^{6}$ cells.

Intranasal administration of MSCs, a promising route for stem cell delivery in patients with neurodegenerative diseases, provided rapid migration of MSCs to the CNS, where they were detected 1-2 hours after the transplantation, but were not found 72 hours later. Despite such rapid migration and elimination from the CNS, the researchers recorded a regression of neurological symptoms in the patients of this group. This effect is explained by the action of neurotrophic secretion factors through the production of exosomes [45]. It is in the exosomes of MSCs of various origins that there are about 676 types of proteins that have pro-regenerative and immunomodulatory properties, so as a therapeutic agent for MS can be considered not only MSCs themselves, but also exosomes isolated from them [46].

The safety and efficacy of umbilical cord MSCs in patients with progressive MS are the subject of a phase I clinical study (NCT02034188) that included patients aged 18-55 years who underwent intravenous administration of allogeneic umbilical cord MSCs daily for 7 days. The study confirms the safety of the use of allogeneic MSCs of the umbilical cord at different stages of MS without any side effects, except for transient cephalgia and general weakness within 1 month after the procedure. The progression of MS stopped after 1 year in more than $80 \%$ of patients, which was confirmed by the results of control MRI [47].

The main routes of administration of MSCs are intravenous and intrathecal. The intravenous route is less invasive and can provide a systemic effect of MSCs on the patient's body, however, a large amount of MSCs from the systemic bloodstream is deposited in the lungs, spleen, liver, and very few of them enter the CNS. Although, even with intravenous administration in patients with demyelinating diseases, a positive effect is observed [48]. The intrathecal route of administration ensures that MSCs enter the cerebrospinal fluid directly. Under these conditions, most researchers observed regression of neurological symptoms and clinical remission without changes in the level of cytokines in the peripheral blood of patients with MS. Thus, it was concluded that the local effect of MSCs at the site of lesion in CNS has no systemic effect [49].

The question of the use of autologous or allogeneic MSCs is debatable. There is no doubt that in patients with autoimmune diseases, MSCs may be defective in terms of immunomodulatory and reparative properties [51]. Allogeneic transplantation is possible due to the minimal immunogenicity of MSCs. Numerous studies have shown that allogeneic and even xenogeneic MSCs do not stimulate an immune response when administered to animals. Allogeneic MSCs do not cause rejection in humans [52]. The advantage of allogeneic cultures is the possibility of using them in acute conditions, when there is no time to expand the required dose of autologous cells. Moreover, it is absolutely necessary to use allogeneic MSCs in the treatment of genetic disorders [53].

\begin{tabular}{|c|c|c|c|c|}
\hline & TRIAL & TITLE & TYPE OF INTERVENTION & PHASE \\
\hline 1. & NCT01377870 & $\begin{array}{l}\text { Evaluation of Autologous Mesenchymal Stem Cell } \\
\text { Transplantation (Effects and Side Effects) in Multiple } \\
\text { Sclerosis }\end{array}$ & $\begin{array}{l}\text { Intravenous injection of autologous } \\
\text { BM-MSC }\end{array}$ & Phase $1 / 2$ \\
\hline 2. & NCT03069170 & $\begin{array}{l}\text { Autologous Bone Marrow Derived Stem Cells for the } \\
\text { Treatment of Multiple Sclerosis. }\end{array}$ & $\begin{array}{l}\text { Intravenous injection of autologous } \\
\text { BM-MSC }\end{array}$ & Phase 1 \\
\hline 3. & NCT00273364 & $\begin{array}{l}\text { Stem Cell Therapy for Patients With Multiple Sclerosis } \\
\text { Failing Alternate Approved Therapy- A Randomized Study }\end{array}$ & $\begin{array}{l}\text { Intravenous injection of peripheral blood } \\
\text { hematopoietic stem cells }\end{array}$ & Phase 1 \\
\hline 4. & NCT03778333 & $\begin{array}{l}\text { Mesenchymal Stem Cells for Progressive Multiple } \\
\text { Sclerosis }\end{array}$ & $\begin{array}{l}\text { Intravenous injection of autologous } \\
\text { BM-MSC }\end{array}$ & Phase 1 \\
\hline 5. & NCT02034188 & $\begin{array}{l}\text { Feasibility Study of Human Umbilical Cord Tissue-Derived } \\
\text { Mesenchymal Stem Cells in Patients With Multiple } \\
\text { Sclerosis }\end{array}$ & $\begin{array}{l}\text { Intravenous injection of allogeneic } \\
\text { umbilical cord mesenchymal stem cells } \\
\text { (UC-MSC) }\end{array}$ & Phase $1 / 2$ \\
\hline 6. & NCT01895439 & $\begin{array}{l}\text { Safety and Efficacy Study of Autologus Bone Marrow } \\
\text { Mesenchymal Stem Cells in Multiple Sclerosis }\end{array}$ & $\begin{array}{l}\text { Intravenous injection of autologous } \\
\text { BM-MSC }\end{array}$ & Phase $1 / 2$ \\
\hline 7 & NCT01606215 & $\begin{array}{l}\text { Stem Cells in Rapidly Evolving Active Multiple Sclerosis } \\
\text { (STREAMS) }\end{array}$ & Injection of autologous BM-MSC & Phase $1 / 2$ \\
\hline
\end{tabular}


Effects of Repeated Mesenchymal Stem Cells (MSC) in Patients With Progressive Multiple Sclerosis (MSC-pMS)

8. NCT04823000

9. NCT00781872

10. NCT02166021

11. NCT03113162

12. NCT03326505

12. NCT02035514

Mesenchymal Stem Cells for the Treatment of MS

Clinical Efficacy of Autologous Mesenchymal Bone Marrow Stem Cells in Active \& Progressive Multiple Sclerosis

Reduced-intensity Immunoablation and Autologous Hematopoietic Stem Cell Transplantation (AHSCT) for Multiple Sclerosis

Allogenic Mesenchymal Stem Cells And Physical Therapy for MS Treatment

Phase I-II Clinical Trial With Autologous Bone Marrow Derived Mesenchymal Stem Cells for the Therapy of Multiple Sclerosis

Best Available Therapy Versus Autologous Hematopoetic

13. NCT04047628 Stem Cell Transplant for Multiple Sclerosis (BEAT-MS) (BEAT-MS)

14. Immunological Mechanisms of Hematopoietic Stem Cell Transplantation in Multiple Sclerosis

15. NCT00395200 Mesenchymal Stem Cells in Multiple Sclerosis (MSCIMS)

Phase I-II Clinical Trial With Autologous Bone Marrow

16. NCT02035514 Derived Mesenchymal Stem Cells for the Therapy of Multiple Sclerosis

Intrathecal Administration of Autologous Mesenchymal

17. NCT01933802 Stem Cell-derived Neural Progenitors (MSC-NP) in Patients With Multiple Sclerosis

18. NCT00342134 Immunological Mechanisms of Hematopoietic Stem Cell Transplantation in Multiple Sclerosis

19. NCT00288626 High-Dose Immunosuppression and Autologous Transplantation for Multiple Sclerosis (HALT MS) Study

Safety and Efficacy of Intravenous Autologous

20. NCT02239393 Mesenchymal Stem Cells for MS: a Phase 2 Proof of Concept Study (MESCAMS)

21. NCT03477500 RCT Comparing Autologous Hematopoietic Stem Cell Transplantation Versus Alemtuzumab in MS (RAM-MS)

22. NCT00813969 Autologous Mesenchymal Stem Cell (MSC) Transplantation in MS

Autologous Mesenchymal Stem Cells From Adipose Tissue in Patients With Secondary Progressive Multiple Sclerosis

24. NCT03799718 Safety and Efficacy of Repeated Administration of NurOwn (MSC-NTF Cells) in Participants With Progressive MS

Phase I Study of High-Dose Cyclophosphamide and Total Body Irradiation With T Lymphocyte-Depleted Autologous Peripheral Blood Stem Cell or Bone Marrow Rescue in Patients With Multiple Sclerosis

Phase I Pilot Study of Total-Body Irradiation, AntiThymocyte Globulin and Cyclophosphamide Followed

\section{By Syngeneic or Autologous Peripheral Blood Stem Cell Transplantation in Patients With Multiple Sclerosis \\ 26. NCT00014755}

Autologous Mesenchymal Stromal Cells for Multiple Sclerosis (EMMES)

\begin{tabular}{|l|r|}
\hline 27. & NCT02495766 \\
\hline 28. & NCT00040482 \\
\hline 29. & NCTO0716066 \\
\hline
\end{tabular}

High Dose Chemo/Radiotherapy and Hematopoietic Stem Cell Transplant for Patients With Multiple Sclerosis

Autologous Peripheral Blood Stem Cell Transplant for Neurologic Autoimmune Diseases
TYPE OF INTERVENTION

PHASE

Intravenous and intrathecal injection of autologous BM-MSC

Injection of autologous BM-MSC

Phase 1/2

Phase $1 / 2$

Intravenous and intrathecal injection of autologous BM-MSC

Phase 2

Injection of autologous BM-MSC

Phase 1

Intravenous injection of allogeneic umbilical cord mesenchymal stem cells (UC-MSC)

Injection of autologous BM-MSC

Phase $1 / 2$

Injection of autologous hematopoietic stem cells

Phase 3

Injection of autologous hematopoietic stem cells

Phase 2

Injection of autologous BM-MSC

Phase 1/2

Injection of autologous BM-MSC

Phase 1/2

Intrathecal injections of culture-expanded autologous MSC-NPS

Phase 1

Injection of autologous peripheral blood hematopoietic stem cells

Injection of autologous peripheral blood hematopoietic stem cells

Injection of autologous BM-MSC

Phase 2

Injection of autologous peripheral blood hematopoietic stem cells

Phase 3

Injection of autologous BM-MSC

Phase 1

Injection of autologous adipose derivedMSC

Phase 1/2

Intrathecal injections of autologous mesenchymal stem cells secreting neurotrophic factors (NTF), MSC-NTF

Phase 2

Injection of autologous peripheral blood hematopoietic stem cells

Phase 1

Injection of autologous peripheral blood hematopoietic stem cells

Phase 1

Injection of autologous BM-MSC

Phase 1/2

Injection of autologous BM-MSC

Phase 2

Injection of autologous peripheral blood hematopoietic stem cells 


\section{CONCLUSION}

MSCs have great potential in the treatment of demyelinating and degenerative CNS diseases. Numerous experimental and clinical studies confirm their safety and effectiveness, but many questions remain open. The scientific data obtained at this stage indicate the need to continue research in this area and their prospects.

\section{REFERENCES:}

1. Thompson AJ, Baranzini SE, Geurts J, Hemmer B, Ciccarelli O. Multiple sclerosis. Lancet. 2018; 391(10130):1622-1636. D0I: 10.1016/S0140-6736(18)30481-1.

2. Kamińska J, Koper OM, Piechal K, Kemona H. Multiple sclerosis - etiology and diagnostic potential. Postepy Hig Med Dosw (Online). 2017; 71(0):551-563. D0I: 10.5604/01.3001.0010.3836

3. Oh J, Vidal-Jordana A, Montalban X. Multiple sclerosis: clinical aspects. Curr Opin Neurol. 2018; 31(6):752-759. D0I:10.1097/WC0.0000000000000622.

4. Axisa PP, Hafler DA. Multiple sclerosis: genetics, biomarkers, treatments. Curr Opin Neurol. 2016; 29(3):345-353. D0l: 10.1097/WC0.0000000000000319

5. Correale J, Gaitán MI, Ysrraelit MC, Fiol MP. Progressive multiple sclerosis: from pathogenic mechanisms to treatment. Brain. 2017; 140(3):527-546. D0I: 10.1093/brain/aww258.

6. Hollenbach JA, Oksenberg JR. The immunogenetics of multiple sclerosis: A comprehensive review. J Autoimmun. 2015; 64:13-25. D0l:10.1016/j.jaut.2015.06.010.

7. Goris $A$, Dubois $B$. Leveraging human genetics to inform intervention strategies for multiple sclerosis. Neurology. 2019; 92(16):735-736. D0I: 10.1212/ WNL.0000000000007298.

8. Canto E, Oksenberg JR. Multiple sclerosis genetics. Mult Scler. 2018; 24(1):75-79. DOI: 10.1177/1352458517737371

9. Yamout BI, Alroughani R. Multiple Sclerosis. Semin Neurol. 2018; 38(2):212-225. DOI: 10.1055/s-0038-1649502.

10. Dendrou CA, Fugger L, Friese MA. Immunopathology of multiple sclerosis. Nat Rev Immunol. 2015; 15(9):545-558. D0l: 10.1038/nri3871.

11. Baecher-Allan C, Kaskow BJ, Weiner HL. Multiple Sclerosis: Mechanisms and Immunotherapy. Neuron. 2018; 97(4):742-768. D0l:10.1016/j.neuron.2018.01.021.

12. Garg N, Smith TW. An update on immunopathogenesis, diagnosis, and treatment of multiple sclerosis. Brain Behav. 2015; 5(9):e00362. D0l: 10.1002/brb3.362.

13. Sospedra M, Martin R. Immunology of Multiple Sclerosis. Semin Neurol. 2016; 36(2):115-127. DOI: 10.1055/s-0036-1579739.

14. Hemmer B, Kerschensteiner M, Korn T. Role of the innate and adaptive immune responses in the course of multiple sclerosis. Lancet Neurol. 2015; 14(4):406-419. DOI: 10.1016/S1474-4422(14)70305-9.

15. Wingerchuk DM, Weinshenker BG. Disease modifying therapies for relapsing multiple sclerosis. BMJ. 2016; 354:i3518. D0I: 10.1136/bmj.i3518.

16. Douvaras $P$, Wang J, Zimmer $M$, et al. Efficient generation of myelinating oligodendrocytes from primary progressive multiple sclerosis patients by induced pluripotent stem cells. Stem Cell Reports. 2014; 3(2):250-259. DOl:10.1016/j.stemcr.2014.06.012.

17. Scolding NJ, Pasquini M, Reingold SC, et al. Cell-based therapeutic strategies for multiple sclerosis. Brain. 2017; 140(11):2776-2796. DOl:10.1093/brain/awx154 .

18. Lee CC, Hirasawa N, Garcia KG, Ramanathan D, Kim KD. Stem and progenitor cell microenvironment for bone regeneration and repair. Regen Med. 2019; 14(7):693-702. DOI: 10.2217/rme-2018-0044.

19. Gonzales-Portillo GS, Sanberg PR, Franzblau M, et al. Mannitol-enhanced delivery of stem cells and their growth factors across the blood-brain barrier. Cell Transplant. 2014; 23(4-5):531-539. DOI: 10.3727/096368914X678337.

20. Ullah M, Liu DD, Thakor AS. Mesenchymal Stromal Cell Homing: Mechanisms and Strategies for Improvement. iScience. 2019; 15:421-438. D0l:10.1016/j. isci.2019.05.004.

21. Aisenbrey EA, Bryant SJ. A MMP7-sensitive photoclickable biomimetic hydrogel for MSC encapsulation towards engineering human cartilage. J Biomed Mater Res A. 2018; 106(8):2344-2355. DOl:10.1002/jbm.a.36412.

22. Shao PL, Wu SC, Lin ZY, Ho ML, Chen CH, Wang CZ. Alpha-5 Integrin Mediates Simvastatin-Induced Osteogenesis of Bone Marrow Mesenchymal Stem Cells. Int J Mol Sci. 2019; 20(3):506. DOI: 10.3390/ijms20030506.

23. Todeschi MR, El Backly R, Capelli C, et al. Transplanted Umbilical Cord Mesenchymal Stem Cells Modify the In Vivo Microenvironment Enhancing Angiogenesis and Leading to Bone Regeneration. Stem Cells Dev. 2015; 24(13):1570-1581. D0I:10.1089/scd.2014.0490.

24. de Witte SFH, Luk F, Sierra Parraga JM, et al. Immunomodulation By Therapeutic Mesenchymal Stromal Cells (MSC) Is Triggered Through Phagocytosis of MSC By Monocytic Cells. Stem Cells. 2018; 36(4):602-615. D0l:10.1002/stem.2779.

25. Munir H, Ward LSC, McGettrick HM. Mesenchymal Stem Cells as Endogenous Regulators of Inflammation. Adv Exp Med Biol. 2018; 1060:73-98. D0I: 10.1007/9783-319-78127-3_5.

26. Regmi S, Pathak S, Kim JO, Yong CS, Jeong JH. Mesenchymal stem cell therapy for the treatment of inflammatory diseases: Challenges, opportunities, and future perspectives. Eur J Cell Biol. 2019; 98(5-8):151041. DOl:10.1016/j.ejcb.2019.04.002.

27. Caplan Al, Sorrell JM. The MSC curtain that stops the immune system. Immunol Lett. 2015; 168(2):136-139. D0I: 10.1016/j.imlet.2015.06.005.

28. Selich A, Ha TC, Morgan M, et al. Cytokine Selection of MSC Clones with Different Functionality. Stem Cell Reports. 2019; 13(2):262-273. D0l:10.1016/j. stemcr.2019.06.001.

29. Le Blanc K, Davies LC. Mesenchymal stromal cells and the innate immune response. Immunol Lett. 2015; 168(2):140-146. D0l:10.1016/j.imlet.2015.05.004.

30. Zhang Q, Fu L, Liang Y, et al. Exosomes originating from MSCs stimulated with TGF- $\beta$ and IFN- $ү$ promote Treg differentiation. J Cell Physiol. 2018; 233(9):68326840. DOI:10.1002/jcp.26436.

31. Aggarwal S, Pittenger MF. Human mesenchymal stem cells modulate allogeneic immune cell responses. Blood. 2005; 105(4):1815-1822. D0I: 10.1182/ blood-2004-04-1559.

32. Bonig H, Kuçi Z, Kuçi S, et al. Children and Adults with Refractory Acute Graft-versus-Host Disease Respond to Treatment with the Mesenchymal Stromal Cell Preparation «MSC-FFM»-Outcome Report of 92 Patients. Cells. 2019; 8(12):1577. DOl:10.3390/cells8121577.

33. Quintiliano K, Crestani $T$, Silveira $D$, et al. Neural Differentiation of Mesenchymal Stem Cells on Scaffolds for Nerve Tissue Engineering Applications. Cell Reprogram. 2016; 18(6):369-381. DOI:10.1089/cell.2016.0024. 
34. Cuascut FX, Hutton GJ. Stem Cell-Based Therapies for Multiple Sclerosis: Current Perspectives. Biomedicines. 2019; 7(2):26. D0I: 10.3390/biomedicines7020026.

35. Akinola Samuel Toluvani. Khirurgichna korektsiya demiєlinizuyuchikh ushkodzhen' tsentral'noï nervovoï sistemi iz zastosuvannyam mezenkhimal'nikh stovburovikh klitin (eksperimental'ne doslidzhennya) [Surgical correction of demyelinating lesions of the central nervous system by using mesenchymal stem cells (experimental study)]. Aavtoref. dis. ... kand. med. nauk - Dissertation abstract: 14.01.05. Kyiv, 2019. 27 p.[in Ukrainian]

36. Castro-Manrreza ME, Montesinos JJ. Immunoregulation by mesenchymal stem cells: biological aspects and clinical applications. J Immunol Res. 2015; 2015:394917. DOI: $10.1155 / 2015 / 394917$.

37. Liu XD, Liu D, Zang CB, et al. IFN- $\gamma$ stimulation enhances immunosuppressive capability of human umbilical cord mesenchymal stem cells. Europe PMC. 2014; 22(3):605-611. DOI:10.7534/j.issn.1009-2137.2014.03.006.

38. Miller RH, Bai L, Lennon DP, Caplan Al. The potential of mesenchymal stem cells for neural repair. Discov Med. 2010; 9(46):236-242.

39. Nessler J, Bénardais K, Gudi V, et al. Effects of murine and human bone marrow-derived mesenchymal stem cells on cuprizone induced demyelination. PLoS One. 2013; 8(7):e69795. DOI:10.1371/journal.pone.0069795.

40. Li T, Xia M, Gao Y, Chen $Y, X u Y$. Human umbilical cord mesenchymal stem cells: an overview of their potential in cell-based therapy. Expert Opin Biol Ther. 2015; 15(9):1293-1306. DOI:10.1517/14712598.2015.1051528.

41. Liu R, Zhang Z, Lu Z, et al. Human umbilical cord stem cells ameliorate experimental autoimmune encephalomyelitis by regulating immunoinflammation and remyelination. Stem Cells Dev. 2013; 22(7):1053-1062. doi:10.1089/scd.2012.0463.

42. Sahraian MA, Mohyeddin Bonab M, Baghbanian SM, Owji M, Naser Moghadasi A. Therapeutic Use of Intrathecal Mesenchymal Stem Cells in patients with Multiple Sclerosis: A Pilot Study with Booster Injection. Immunol Invest. 2019; 48(2):160-168. D0I:10.1080/08820139.2018.1504301.

43. Karussis $D$, Karageorgiou $C$, Vaknin-Dembinsky $A$, et al. Safety and immunological effects of mesenchymal stem cell transplantation in patients with multiple sclerosis and amyotrophic lateral sclerosis. Arch Neurol. 2010; 67(10):1187-1194. D0I:10.1001/archneurol.2010.248.

44. Petrou P, Kassis I, Levin N, et al. Beneficial effects of autologous mesenchymal stem cell transplantation in active progressive multiple sclerosis. Brain. 2020; 143(12):3574-3588. D0I:10.1093/brain/awaa333.

45. Harris VK, Stark J, Vyshkina T, et al. Phase I Trial of Intrathecal Mesenchymal Stem Cell-derived Neural Progenitors in Progressive Multiple Sclerosis. EBioMedicine. 2018; 29:23-30. DOl:10.1016/j.ebiom.2018.02.002/

46. Hosseini Shamili $F$, Alibolandi M, Rafatpanah $\mathrm{H}$, et al. Immunomodulatory properties of MSC-derived exosomes armed with high affinity aptamer toward mylein as a platform for reducing multiple sclerosis clinical score. J Control Release. 2019; 299:149-164. D0I:10.1016/j.jconrel.2019.02.032.

47. Riordan NH, Morales I, Fernández G, et al. Clinical feasibility of umbilical cord tissue-derived mesenchymal stem cells in the treatment of multiple sclerosis. J Transl Med. 2018; 16(1):57. D0l:10.1186/s12967-018-1433-7/

48. Uccelli A, Laroni A, Brundin L, et al. MEsenchymal StEm cells for Multiple Sclerosis (MESEMS): a randomized, double blind, cross-0ver phase I/II clinical trial with autologous mesenchymal stem cells for the therapy of multiple sclerosis. Trials. 2019; 20(1):263. D0I: 10.1186/s13063-019-3346-z.

49. Harris VK, Stark J, Vyshkina T, et al. Phase I Trial of Intrathecal Mesenchymal Stem Cell-derived Neural Progenitors in Progressive Multiple Sclerosis. EBioMedicine. 2018; 29:23-30. DOI:10.1016/j.ebiom.2018.02.002.

50. Available: https://clinicaltrials.gov

51. Yang H, Sun J, Wang F, Li Y, Bi J, Qu T. Umbilical cord-derived mesenchymal stem cells reversed the suppressive deficiency of T regulatory cells from peripheral blood of patients with multiple sclerosis in a co-culture - a preliminary study. Oncotarget. 2016; 7(45):72537-72545. D0I:10.18632/oncotarget.12345.

52. Stagg J, Galipeau J. Mechanisms of immune modulation by mesenchymal stromal cells and clinical translation. Curr Mol Med. 2013; 13(5):856-867. D0I:10.217 4/1566524011313050016.

53. Harrell CR, Fellabaum C, Jovicic N, Djonov V, Arsenijevic N, Volarevic V. Molecular Mechanisms Responsible for Therapeutic Potential of Mesenchymal Stem Cell-Derived Secretome. Cells. 2019; 8(5):467. D0I:10.3390/cells8050467

\begin{tabular}{|c|c|}
\hline ARTILE ON THE SITE \\
\hline TRANSPLANTOLOG.ORG \\
\hline
\end{tabular}

The authors declared no potential conflicts of interest with respect to the research, authorship, and/or publication of this article. 
УДК 616.832-004.2:576.3-085

\section{Трансплантація мезенхімальних стовбурових клітин для лікування демієлінізуючих захворювань}

П Петрів Т. І. ${ }^{1,2,3}$, Татарчук М. М. ${ }^{1}$, Цимбалюк Ю. В. ${ }^{1}$, Цимбалюк В. I. ${ }^{4}$

${ }^{1}$ Державна установа «Інститут нейрохірургї ім. А. П. Ромоданова Національної академії медичних наук України», Київ, Україна

${ }^{2}$ Медичний центр «Гемафонд», Київ, Украӥна

${ }^{3} \mathrm{QR}$ Health Solutions, Київ, Україна

${ }^{4}$ Національна академія медичних наук України, Київ, Україна

\section{PE3ЮME}

Демієлінізуючі захворювання, особливо розсіяний склероз, є не лише медичною, але й соціально-економічною проблемою. Незадовільна якість життя та високий ступінь інвалідності у цих пацієнтів вимагають застосування передових методів лікування, таких як трансплантація стовбурових клітин. Проводяться численні експериментальні та клінічні дослідження, що виявляють нові механізми дії стовбурових клітин при демієлінізуючих захворюваннях. Потрібні подальші дослідження, щоб зрозуміти багато інших аспектів клінічного використання клітинної терапії при патології центральної нервової системи.

Даний огляд присвячений використанню регенеративних технологій у лікуванні демієлінізуючих захворювань, сучасному стану та перспективним підходам до клітинної терапії даної патології.

ключовІ СлОВА: стовбурові клітини; клітинна трансплантація; розсіяний склероз 